\title{
General Characteristics of the Financial Markets in the People's Republic of China
}

\author{
Maria Arakcheeva
}

2th-year undergraduate student, International Finance Faculty,

Financial University, Moscow, Russia

m.arakcheeva1@gmail.com

Abstract

In this article the author presents the main characteristics of the economy of the People's Republic of China. First of all, the Chinese government has a prudent policy of gradual opening and liberalisation of the economy. However, significant impact on economic development and the state of international settlements in the Asian region is influenced by currency and monetary policy. Therefore, for Chinese state authorities maintenance of stable national currency becomes especially important. In the early 1980 s, the government began opening the banking system and the four state-owned specialised banks to accept deposits and perform banking activities. Also, the author analysed development of financial markets of the People's Republic of China. Finally, the author discussed the emerging markets of bitcoin and cryptocurrencies in China.

Keywords: People's Republic of China; monetary policy; economic growth; cryptocurrencies; Chinese stock exchanges; renminbi

JEL Classification: D53, G15, G23, G28

\section{The economy of the People's Republic of China}

As we all know, the economy of China has some advantages. First and foremost, almost inexhaustible labour resources: labour force is very motivated, the work ethics of Chinese labour is at the highest level, and Chinese people commit to real education (Brown, 2009, pp. 321-323).

Despite the absence of the political parties, the political system of the country is arranged in such a way that there are competition and a real alternation of power. Hence, there exists an effective system of state regulation and economic policy, as well as the enormous public investment in infrastructure development.

Also, the country makes enormous investments in research and development (R\&D). According to last available data (OECD Data, a) total gross domestic spending on R\&D as\% of GDP was in 20162.108 per cent for the People's Republic of China and 1.097 per cent for Russian Federation. That is why China is approaching to be the most developed country.
Moreover, it should be noted that for China exists a very high rate of savings. It is one of the highest in the world - according to last available data (OECD Data, b) saving rate was 46.9 per cent of GDP in 2015. For Russia, this figure was equal to 15.3 per cent in 2015. It was achieved thanks to the low tax burden.

Due to these factors, the country has a very high level of monetisation of the economy. The four largest banks of the country are among the ten largest banks in the world by capital and assets. Due to the developed financial system, the domestic stock market is highly developed too. With the help of IPO and issuing of shares in the domestic market, the contribution to the economy is up to 100 billion U.S. dollars annually. Two largest Chinese stock exchanges by market capitalisation and turnover are among the ten largest in the world (Kroeber, 2016, pp. 246-250).

The government has a prudent policy of gradual opening and liberalisation of the economy. There still are severe restrictions on foreign portfolio investment, restrictions on capital balance. However, there is a general trend to openness, including the 
transformation of the Chinese currency - yuan or renminbi into a global currency. It is worth to mention the increased income inequality. Here the damping factor is Confucianism as the basis of social conduct and anti-corruption policy of the Chinese Communist Party (Yu, 2012, pp. 194-201).

At the same time, it should be noted that many risks exist in the Chinese economy. First and foremost, there exists the possibility of «overheating» of the economy and creating excess capacity. Furthermore, there is an environmental problem (Shenggen et al., 2014, pp. 305-316). It should lead to an inevitable slowdown in the gradual elimination of the low base effect. Another important risk factor is the gradual reduction of the effect of cheap labour at the expense of the welfare of the population.

Significant impact on economic development and the state of international settlements in the Asian region is influenced by currency and monetary policy. Cash-credit policy is directed mainly by regulation of inflation, unemployment, economic growth, financial stabilisation and maintenance of stable national currency. Maintenance of stable national currency becomes especially important in connection with the recent trends; however, in similar conditions, the state authorities in different countries have used different approaches to overcome crises (Hossain, 2015, pp. 574-578).

The currency of China is Renminbi (is written by three hieroglyphs: 人民币, translated like “people's currency") or Yuan (Chinese writing: 元). The interbank exchange rate on February 28, 2019, was \$US = 6.6182607 CNY (https://www.hsbc. com.cn/1/2//misc/exchange-rates/). The yuan has divided into 100 fens each or 10 jiao. Coins come in denominations of one, two and five fens each; one and five jiao, and one yuan coin. Banknotes come in denominations of one, two and five jiao; and one, two, five, 10, 50 and 100 yuan.

The Renminbi is issued and controlled solely by the People's Bank of China. The exchange rate of yuan is determined by the People's Bank of China and issued by the state administration of foreign exchange, the latter exercising the functions and powers of exchange control (Zhang, 2012, pp. 187-189). In 1994 China made the reformation of the foreign exchange system, combined the RMB exchange rate adopted by settlement systems of the Bank exchange and created a unified inter- bank foreign exchange market. On 1, December 1996, China officially recognised article 8 of the Agreement on international currencies and funds and realised RMB convertibility under the current account ahead of schedule.

\section{The interbank exchange rate of the renminbi}

Meanwhile, China is actively involved in promoting bilateral currency exchange between ASEAN, Japan, and the Republic of Korea. A variety of financial companies is growing steadily; China opened several new companies to integrate into various aspects of modern international financial business, such as consumer credit, securities investment funds, and insurance-linked investments (Minikin \& Lau, 2012, p. 208).

The banking system in China used to be monolithic, with the People's Bank of China (PBC), the Central Bank, as the primary entity authorised to conduct operations in this country. In the early 1980s, the government began opening the banking system and the four state-owned specialised banks to accept deposits and perform banking activities. These four specialised banks are the Industrial \& Commercial Bank of China (ICBC), China Construction Bank (CCB), Bank of China (BOC) and Agricultural Bank of China (ABC).

In 1994, the Chinese government established three more banks, each dedicated to a specific purpose of lending. These policy banks include the Agricultural Development Bank of China (ADBC), the China Development Bank (CDB) and the Export-Import Bank of China. Four specialised banks all held initial public offerings and have a different degree of ownership by the public. Despite these IPOs, banks are still majority owned by the Chinese government.

China also allowed a dozen joint-stock commercial banking institutions and more than one hundred urban commercial banks in the country. There are also banks in China dedicated to rural areas of the country. Foreign banks are also allowed to establish branches in China and to make strategic investments minority in many stateowned commercial banks.

The main national regulatory body that controls China's banking system is the China Banking Regulatory Commission (CBRC), which is charged with writing rules and regulations governing banks 
in China. The CBRC conducts inspections and monitors activities of banks, collects and publishes statistical data on the banking system, approves the establishment or expansion of banking activities and addresses potential liquidity, solvency and other problems that may arise in individual banks (Sanderson \& Forsythe, 2013, pp. 204-210).

The People's Bank of China also has considerable power over the Chinese banking system. In addition to the typical issues, the Central Bank is responsible for monetary policy and representing the country at the international forum, the role of the $\mathrm{PBC}$ is to reduce the risks and increase the stability of the financial system. The PBC also regulates credit and currency transactions between banks and supervises the payment and settlement system.

\section{Financial markets of the People's Republic of China}

The 2008 crisis led to a significant decline in all economic indicators of the countries of the Asian region. The countries managed to return to the pre-crisis level of the economy only in 2010-2011 years. However, starting from 2014 in conditions of continuing external shocks from the international markets of oil and gas, metals, falling exchange rates, and other issues, in many countries problems with the current balance of payments and inflow of foreign currency occurred.

As for the 2019 year, economic growth slowed again in the fourth quarter as spillovers from both financial deleveraging earlier in the year and the trade spat between China and the United States continue to weigh on economic activity. Although policy easing is preventing the economy from decelerating sharply and the slowdown appears to be manageable for now, risks are mounting.

To bolster the economy, Chinese authorities are expected to ease fiscal and monetary conditions further this year as outlined at the December Central Economic Work Conference. Moreover, although trade talks with the U.S. seem to be making progress, the March deadline for new tariffs is looming with no concrete results yet (Focus Economics, 2019).

Economic growth will remain lacklustre this year on the back of moderating domestic growth amid trade tensions between China and the U.S. Although authorities will rely on fiscal and monetary policy support to avoid any sharp slowdown, the scale of the policy stimulus will be rather limited compared to previous initiatives. Focus Economics panellists see the economy growing 6.2 per cent in 2019 , which is down 0.1 percentage points from last month's forecast, before decelerating slightly to 6.0 per cent in 2020 .

For the past 25 years, China has demonstrated a phenomenal growth of financial depth of the economy. A similar level of financial depth puts China in some countries with the most developed financial system. Such a high rate is associated with some factors. The factors are the following: high savings rate; currency legislation and the overall regulatory system, which made it difficult to transfer savings abroad or to have the appearance of savings in foreign currency cash; reliability of the banking system in the eyes of the public and credibility; relatively moderate rate of inflation; the relatively limited financial products. The latter circumstance facilitated the presence of Chinese population to the stock market (Ming et al., 2014, pp. 168-175).

Deposits make approximately half of the money supply. Most of the financial assets of China are concentrated in the banking system. Bank credit remains the primary source (about 80 per cent) of funding for Chinese enterprises. The corporate bond market is virtually nonexistent. The share of outstanding non-banking corporate bonds is less than 1 per cent of GDP. A dominant position in the banking sector is concerned with five state banks (Andrew Collier, 2017, pp. 164-175.). The five largest and most powerful of them are:

1. Industrial and Commercial Bank of China (ICBC) - the largest Bank in the country that was initially responsible for the lending of industry.

2. Bank of China (BOC) is the second largest and most profitable Bank. Traditionally it was responsible for foreign exchange transactions and foreign trade financing. It has an extensive network of foreign branches and subsidiaries.

3. China Construction Bank (CCB). Its traditionally main activities are crediting of construction of infrastructure facilities.

4. Agricultural Bank of China (ABC) was primarily engaged in lending of agriculture and the development of the agricultural sector. Fourth place is stated by size. However, ABC is the weakest by power among the five largest. 


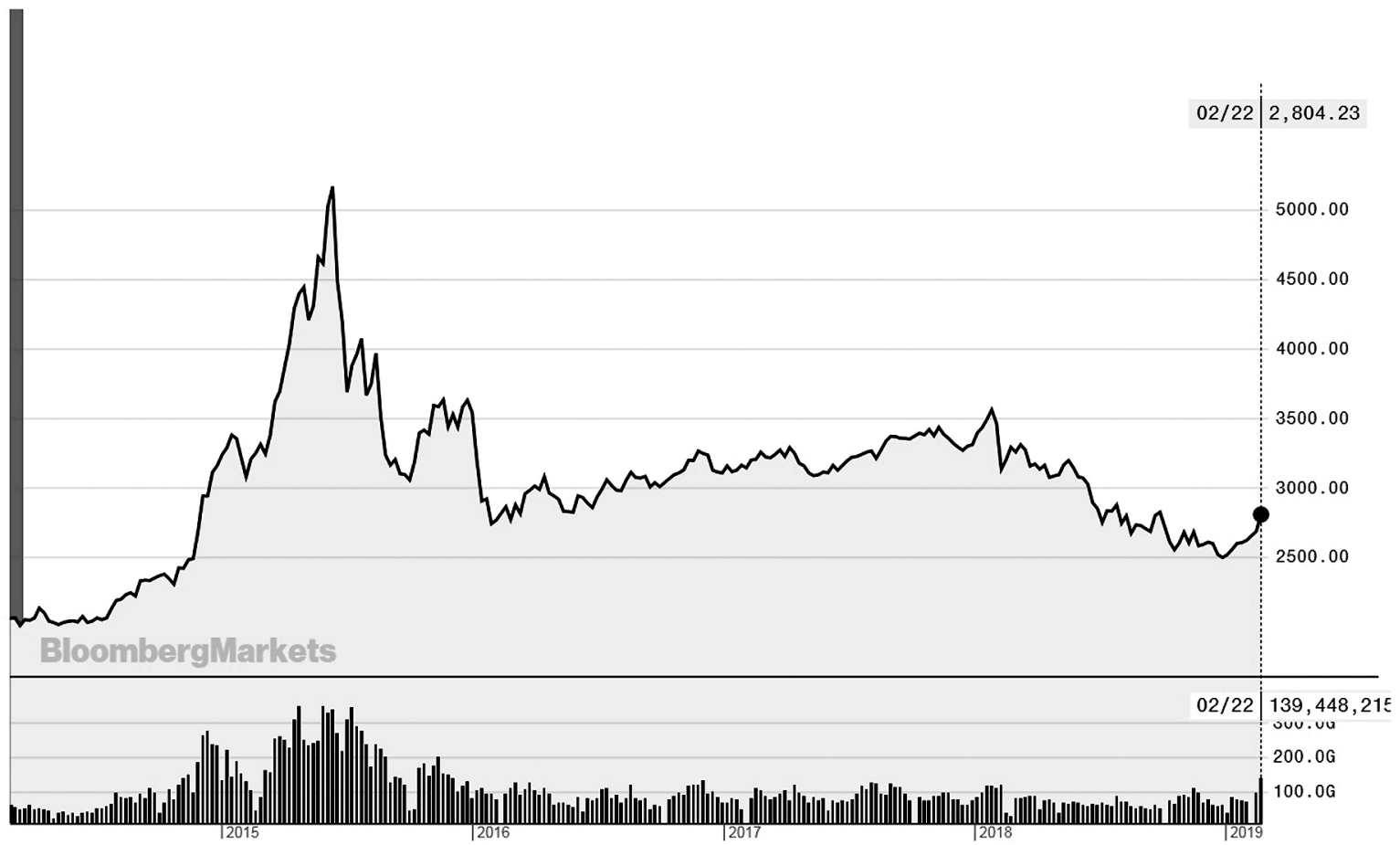

Fig. 1. 5-year SSE Composite index.

Source: Bloomberg. https://www.bloomberg.com/quote/SHCOMP: IND.

5. Bank of Communications (BoCom) was founded in 1985, but joined the group of state banks only in 2007 and previously belonged to the category of joint-stock commercial banks.

Currently, all the banks in the Big Five are diversified commercial banks working in different areas. They have more than 200 thousand offices and about 1.5 million employees. To fulfil the targets of the government three specialised state banks were founded: China Development Bank (CDB), Agricultural Development Bank of China and The Export-Import Bank of China. They do not accept deposits and engage in lending for long-term projects by issuing bonds and loans of other banks. The second group of banks (approximately 14 per cent of assets) in the Chinese statistics is called "joint-stock commercial banks". Four hundred forty institutions, 29 of which are the head offices of the mentioned banks, represent foreign banks.

To sum up, a feature of China's banking system is a complete dominance of state banks. The share of private banks in the assets does not exceed a few percents. The policy of changing the structure of ownership will not lead to radical changes in its structure. The government has developed a program for the recovery of the banking system. It has issued special treasury bonds amounting to 270 billion yuan, the proceeds of which were used to recapitalise the state banks.

Unlike Japan, where the national banks have aggravated the problem of public debt, China has managed to maintain healthy public finances (Lou et al., 2008, pp. 260-266). Also, the commercial banks used their own resources and capital to write off bad loans. Besides the apparent progress in reducing the share of bad loans, the quality of loans has considerably improved in the current decade. Overall, to the current year, China's banking system has significantly improved all the indicators of capital adequacy, quality of loans and other issues of the financial market.

The full operation of the Chinese stock market began with the foundation of the Shanghai Stock Exchange in December 1990. Six months later the Stock Exchange in Shenzhen was opened. Shenzhen is the most successful special economic zone of China. In the period from 2000 to 2004, a multi-level system of the stock market was formed. As is customary throughout the world there were "blue chips" and shares of several echelons (Green, 2003, pp. 105-114.

In 2004, the Chinese government officially allowed Chinese citizens to trade in the stock market. Even though over the past years a variety of Chinese financial instruments has increased, 


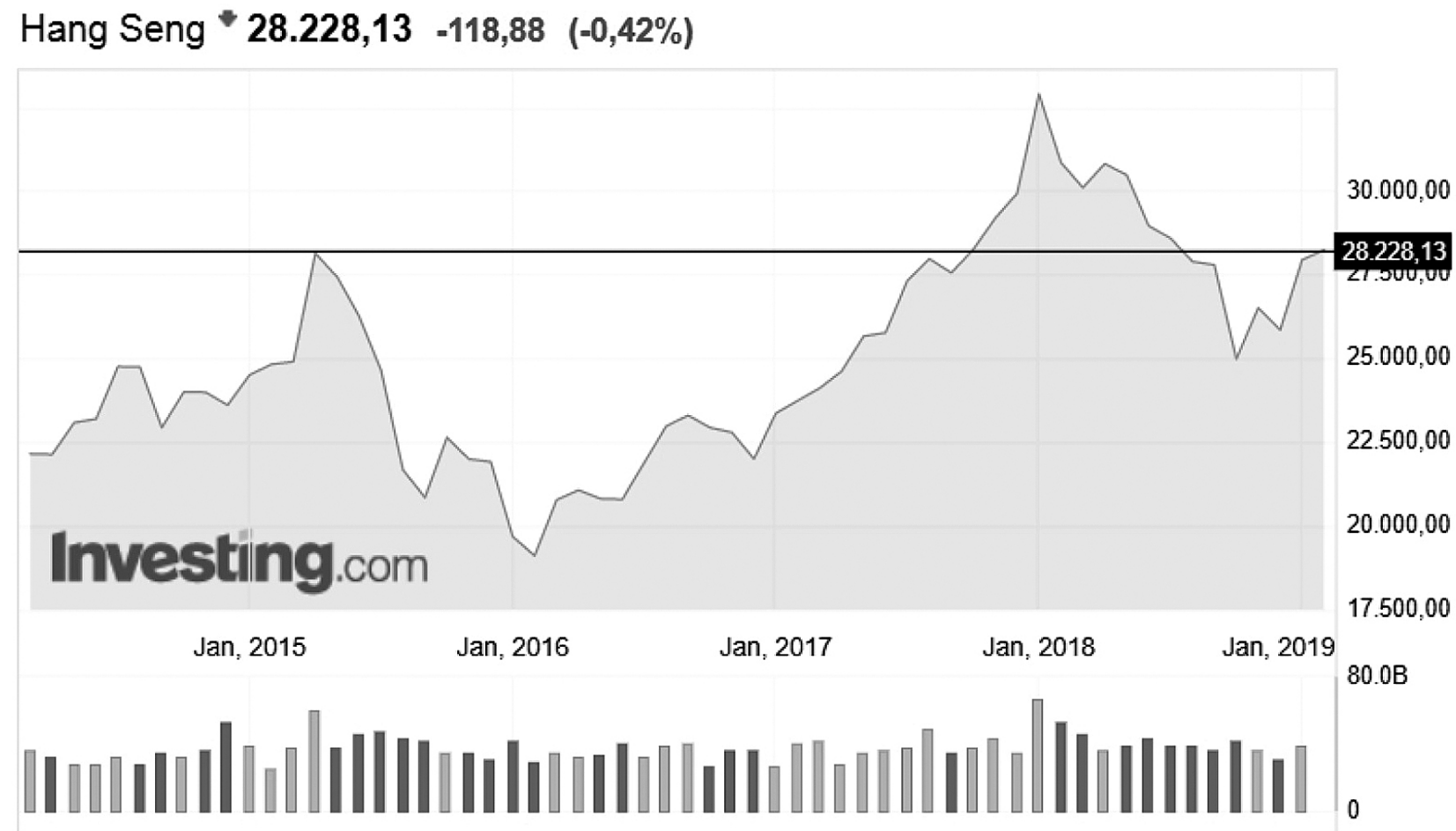

Fig. 2. Hang Seng Index.

Source: Investing.com https://ru.investing.com/indices/hang-sen-40.

it still lags behind the exchanges of developed countries. By 2011, many new financial products were created. These products became an addition to traditional stock, bond, mixed units, currency, and index of insurance shares etc. China has set the creation of the country's international financial centre as one of the priority objectives of economic development. According to Chinese analysts, it will occur in 2025-2030. About the same time, the yuan will turn into a primary world currency. The processes occurring in the Chinese stock market will have an increasing impact on the global economy in general (Yulu, 2013, p. 157).

Shanghai Stock Exchange (Chinese: 上海证券 交易所) is the largest stock exchange of mainland China, one of the leading Asian exchanges. It is founded in 1990, registered as a nonprofit organisation, managed by the Securities Commission. Due to its operating power, the Shanghai Stock Exchange is considered one of the most productive in the world (Shanghai Stock Exchange, 2016, pp. 14-18).

To analyse the status and development of the national stock market, the exchange calculates the SSE Composite index, reflecting the dynamics of all exchange-traded equity securities, and the
SSE 50 index, characterising the value of the 50 blue chips of China.

The most significant pick was in the $2^{\text {nd }}$ quarter of 2015 due to the positive changes in the Chinese stock market. Currently, as for 28/02/2019, the index equals 2682. Today the prospects of Shanghai as a financial centre of China remain quite clear, and there are no prerequisites for any changes. The largest state-owned financial, insurance, industrial corporations have traded their shares in Shanghai for a long time: China Unicom, China Railway Construction, Bank of Communications, Air China, Hainan Airlines, SAIC Motor, Industrial and Commercial Bank of China. Undoubtedly, the presence of such players on the Shanghai Stock Exchange confirms its influence on the Chinese economic scene (Wen-Hsin, 2007, pp. 246-248).

Shenzhen Stock Exchange (Chinese: 深圳证券 交易所) is one of the three major stock exchanges in China and one of the largest in Asia. Although its exact market capitalisation is continuously changing, everybody can definitely say that it is in the ten largest Asian stock exchanges. Shenzhen Stock Exchange was founded in 1990 in the city of Shenzhen. According to the year 2017, there are more than 1,900 companies listed on the Shenzhen Stock Exchange (Shenzhen Stock Exchange, 
2016, pp. 12-24). Shenzhen stock exchange supports multiple indexes. Investors can directly trade these indexes, which include the best companies in different categories. Moreover, the index may be used as economic indicators analysts, exploring the development trends of the Chinese economy and carrying out financial planning.

Hong Kong stock exchange (Chinese: 香港交 易所) is a stock exchange situated in Hong Kong. Ranks $6^{\text {th }}$ in the world in terms of capitalisation of exchange-traded companies. During the financial crisis of 2008, the stock exchange of Hong Kong came to first position globally in attracting capital. According to the analytics, Hong Kong surpassed the previous leader - a trading platform in Shanghai and stock exchanges of Brazil and New York. On the Hong Kong stock exchange shares, bonds, warrants, mutual funds, ETFs and other securities are traded (HKEX, 2016, pp. 11-14).

The most known index is Hang Seng index or HIS shortly. It can be called a survivor, as it began on 24 November 1969 and currently its quotes is the most popular indicator of the health of the Hong Kong stock market. One of the brightest representatives, whose quotes are included in the calculation, is HSBC Holdings, as well as the stock exchange HKEx. Below there are the futures quotes on the main index.

The most significant pick was on 01/01/2018 due to the positive changes in the Chinese stock market. Nowadays the situation is in a more negative position. However, the Hang Seng index is growing after the dramatic downturn in 2016. Currently, the index equals to 28228 .

The Chinese market is an essential segment of the national economy of China. Currently, units of a foreign currency constitute the largest business component of the global financial market. The exchange rate in China depends on the exchange rate of the yuan against other foreign currencies. The currency exchange rates in China keep on oscillations in accordance with changes in international trade and the scenario of trade. With the recent growth of international trade in China, the yuan also traded as valuable currency in the Forex market to a great extent. RMB exchange rate determined by the Chinese Central Bank depends on some factors. These factors include the trading volume of the yuan, the supply of yuan in the Forex market and other factors (Goldstein \& Lardy, 2008, pp. 204-208).
Banks and foreign trading companies do operations with foreign currency in China. These entities offer reliable services to its customers, as well as educational courses. With the help of the object of Forex trading via the Internet, foreign exchanges can be traded 24 hours a day and seven days a week. A large number of sites in China offer reliable information about the Chinese foreign exchange market and exchange rates prevailing in the market. Monetary institutions in China are providing updated information for Forex traders, online Forex, investors in China find it convenient for achieving their financial goals.

\section{Bitcoin and cryptocurrencies in China}

As it is said by bitcoin founder Satoshi Nakamoto in the abstract of his fundamental work: "A purely peer-to-peer version of electronic cash would allow online payments to be sent directly from one party to another without going through a financial institution. Digital signatures provide part of the solution, but the main benefits are lost if a trusted third party is still required to prevent double-spending. We propose a solution to the double-spending problem using a peer-to-peer network. The network timestamps transactions by hashing them into an ongoing chain of hash-based proof-of-work, forming a record that cannot be changed without redoing the proof-of-work.

The longest chain not only serves as proof of the sequence of events witnessed but also proof that it came from the largest pool of CPU power. As long as nodes that are not cooperating to attack the network control a majority of CPU power, they will generate the longest chain and outpace attackers. The network itself requires minimal structure. Messages are broadcast on a best effort basis, and nodes can leave and rejoin the network at will, accepting the longest proof-of-work chain as proof of what happened while they were gone." (Nakamoto, 2008)

China is a major hub for the bitcoin economy in the world. Three Chinese bitcoin exchanges occupy an essential place in the market - they are more than 80 per cent of exchange transactions. Commission for currency control ordered to check the financial institutions and to prevent the outflow of capital. Currency war in the region has led to massive capital losses in the 'Black Monday', from which China began the tough financial week. 
Table 1

Trading volume (BTC)

\begin{tabular}{lcc}
\hline & Country & Trading volume (BTC) 01.01.2017 \\
\hline 1 & China & $104,000,000$ \\
2 & United States & $2,210,000$ \\
3 & Japan & 868,000 \\
4 & European Union & 493,000 \\
5 & United Kingdom & 63,000 \\
6 & Russian Federation & 30,300 \\
7 & Canada & 18,100 \\
8 & Australia & 10700 \\
9 & Singapore & 8,550 \\
10 & Switzerland & 150 \\
11 & South Korea & 117 \\
\hline
\end{tabular}

Source: http://data.bitcoinity.org/markets/volume/5y/CNY?c=e\&t=b.

Table 2

Ratio Trading volume/Number of nodes

\begin{tabular}{ccccc}
\hline & Country & $\begin{array}{c}\text { A - Trading volume (BTC) } \\
\mathbf{0 1 . 0 1 . 2 0 1 7}\end{array}$ & $\begin{array}{c}\text { B - Number of nodes as of } \\
\mathbf{0 1 . 0 1 . 2 0 1 7}\end{array}$ & A/B \\
\hline 1 & China & $104,000,000$ & 208 & 500,000 \\
2 & Japan & $2,210,000$ & 88 & 9,864 \\
3 & United States & 868,000 & 2,011 & 1,099 \\
4 & United Kingdom & 493,000 & 250 & 252 \\
5 & Russian & 63,000 & 186 & 163 \\
6 & European Union & 30,300 & 3,237 & 152 \\
7 & Australia & 18,100 & 83 & 129 \\
8 & Singapore & 10700 & 105 & 81 \\
9 & Canada & 8,550 & 308 & 59 \\
10 & South Korea & 150 & 76 & 2 \\
11 & Switzerland & 117 & 105 & 1 \\
\hline
\end{tabular}

Source: Bitcoin nodes https://bitnodes.21.co.

It caused interest in alternative currencies, and purchase volume of bitcoins in China has increased. Chinese exchanges have led to the appreciation of the U.S. exchanges. Buying bitcoins, gold, and precious metals actually are not something new for China. The volume of gold reserves of the country in 2009 increased by 60 per cent. Banks regulate this field to stop the devaluation of the yuan. The primary objective of the financiers is to reduce the volatility, to curb capital outflows and limit the pressure on the yuan. Trade bitcoin for yuan captures the central part of the market (Sagona-Stophel, 2015, pp. 12-14). 
The fear of impending inflation is pushing to switch to other international platforms. However, the People's Bank of China makes it increasingly difficult for the purchasing of traditional stocks, bonds, and other assets. Because of this, the volume of transactions with bitcoin in China is growing (Kapron, 2014, pp. 21-25).

The three significant exchanges trading bitcoins for Chinese yuan have an amount close to 1 million bitcoins a day. Goldman Sachs reported that 80 per cent of bitcoin transactions are traded in RMB. Overall volumes on the Chinese exchanges are showing growth in the field of digital currency. The devaluation of the Chinese currency is very real, and the stock market shakes regularly. Bitcoin has become a haven, such as gold and silver, which are happy to buy Chinese buyers. The continued devaluation of the Yuan will help large investors to come into the market for bitcoins. The above table represents the trading volume of bitcoins in the world.

The first place by the trading volume at the beginning of the 2017 year was occupied by China. The second - the USA which trading volume is 47 times lower compared with the Chinese. The third position was taken by Japan. That is why these Asian countries were chosen as the main leaders for the bitcoin-based integration. Nevertheless, the Korean trading volume is lower; Korea is an essential hub for cryptocurrencies and mining in this region.

The second table of this chapter represents the new ratio: Trading volume divided by the number of nodes. First of all, it is necessary to determine the so-called nodes in bitcoin sphere. A full node is a program that validates transactions and blocks. Almost all full nodes to help the network and the transactions taking blocks from other full nodes that verify these transactions and blocks, and then passing them in the future full nodes. Most full nodes also serve light clients, allowing them to transmit their operations to the network and to notify them when a deal involves their wallet.

If not enough nodes to perform this function, customers will not be able to connect via peer-topeer network - they have instead of using centralised services. Many people and organisations volunteer to run full nodes using spare computing resources and resources - but the bandwidth more volunteers needed for Bitcoin to continue to rise.

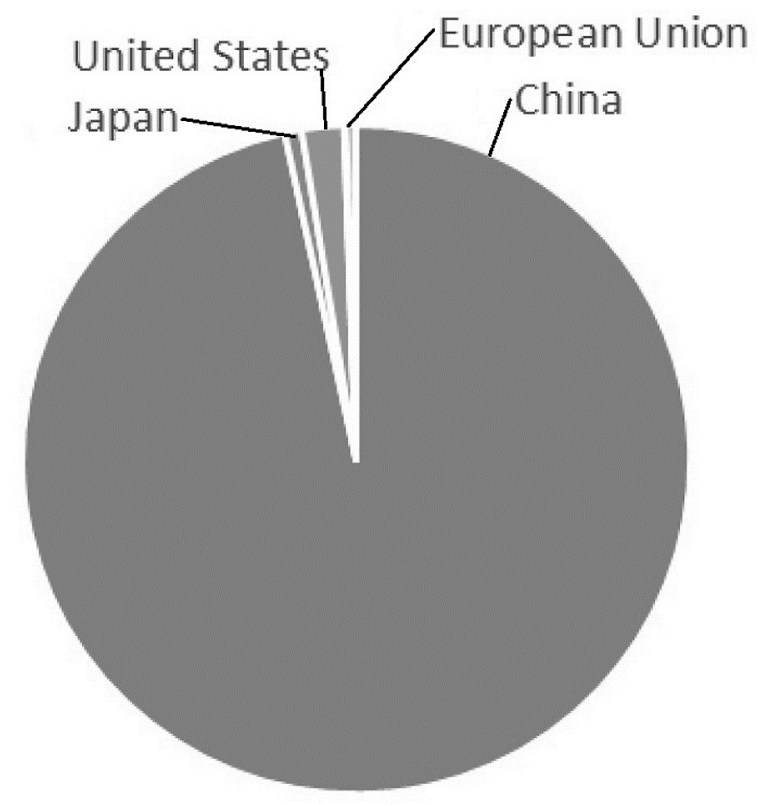

Fig. 3. China as the leader and the driver for integration.

Source: author's calculations.

After determining the leading positions of the equation, it is possible to analyse the presented table. The ratio of Trading volume/Number of nodes represents the capacity of each market. The leaders in this sphere have an excellent opportunity to develop the bitcoin market in the short-run.

China is the leader with the enormous trading volume then go to Japan and the USA. The largest number of nodes is the European Union; however, it takes an only sixth position in the ranking. The gap between China and Japan is quite large, but this gap tends to narrow as the bitcoin market develops all over the world. South Korea occupies the $10^{\text {th }}$ position out of 11 . Nevertheless, South Korea is in the $4^{\text {th }}$ place in the Asian region after China, Japan, and Singapore. That is why Korea still has a good position among Asian bitcoin markets.

The Chinese leadership is based on the great variety of facts. From the beginning of 2017, Bitcoin traders were focused on the events taking place between the Central Bank of China and bitcoin exchanges residing in the country.

However, over the past half the year of 2017, the withdrawal was suspended in almost all major Chinese bitcoin trading platforms. The 2017 year showed shakeup in relation to the Chinese bitcoin exchanges, as each company is faced with the legal wrath of the People's Bank of China (PBOC). Regularly review and discussions led to the tightening 


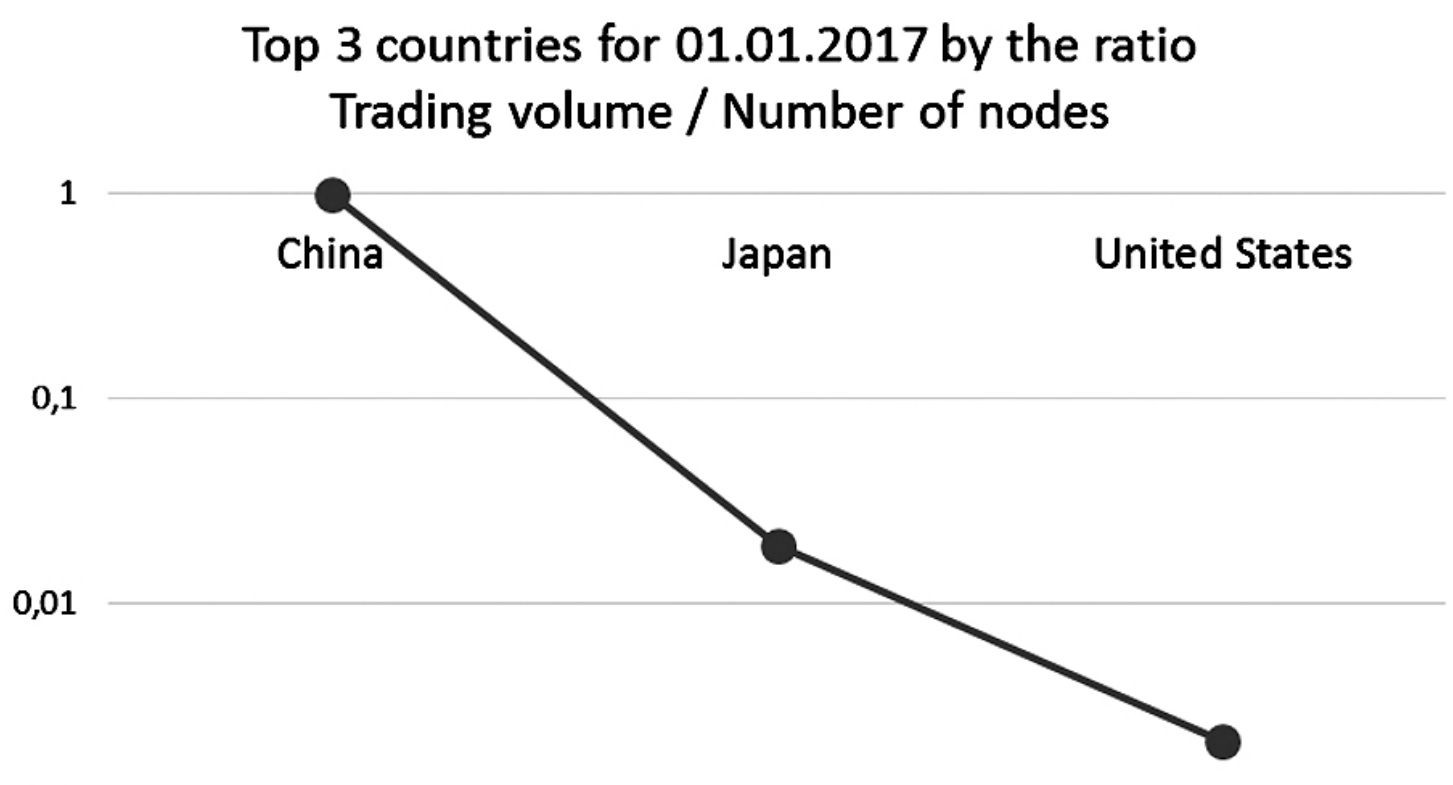

0,001

Fig. 4. Top three countries by ratio Trading volume/Number of nodes.

Source: author's calculations.

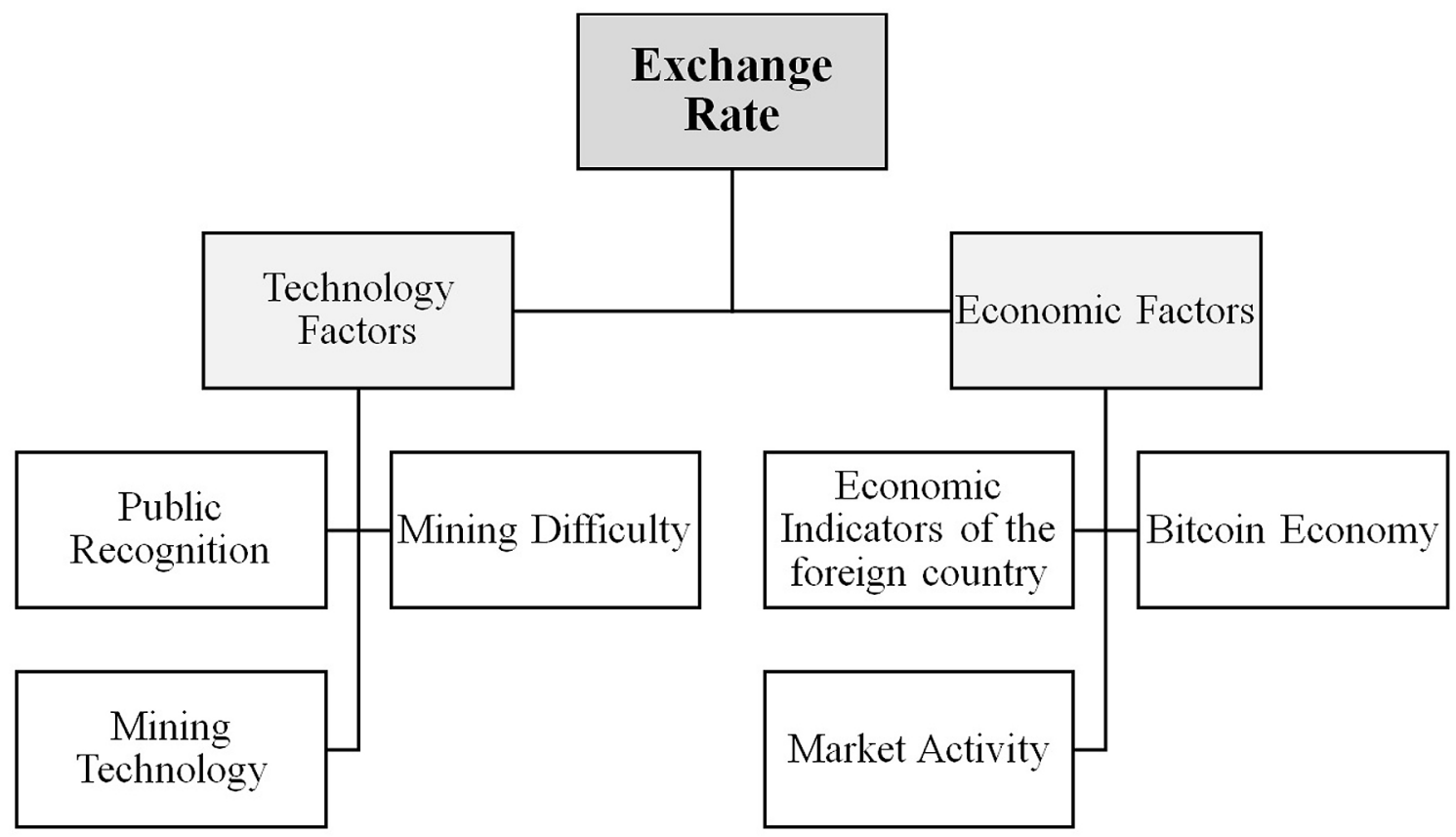

Fig. 5. Technology and economic factors of mining and bitcoins circulation.

regulation, and Chinese merchants are unable to withdraw bitcoins for two months. Chinese trading platform also revealed new types of control on-the-spot checks and detection.

The light revealed the platform update for multi-signature system output, but not full, when the company will lift the suspension. After April 23, the company's customers will use a multi-signature controlled Wallet for bitcoin and Litecoin
Company. The other two top bitcoin exchanges in China recently told the public that not all bitcoin exchanges in China are adhering to the new regulatory policy and the payments must begin after completion of the upgrade process.

It is evident from the pie chart that China is the leader in the determined ratio. The ratio Trading volume/Number of nodes shows the current situation in the market and determines the pos- 
Table 3

Comparison between the Early Market and Later Market

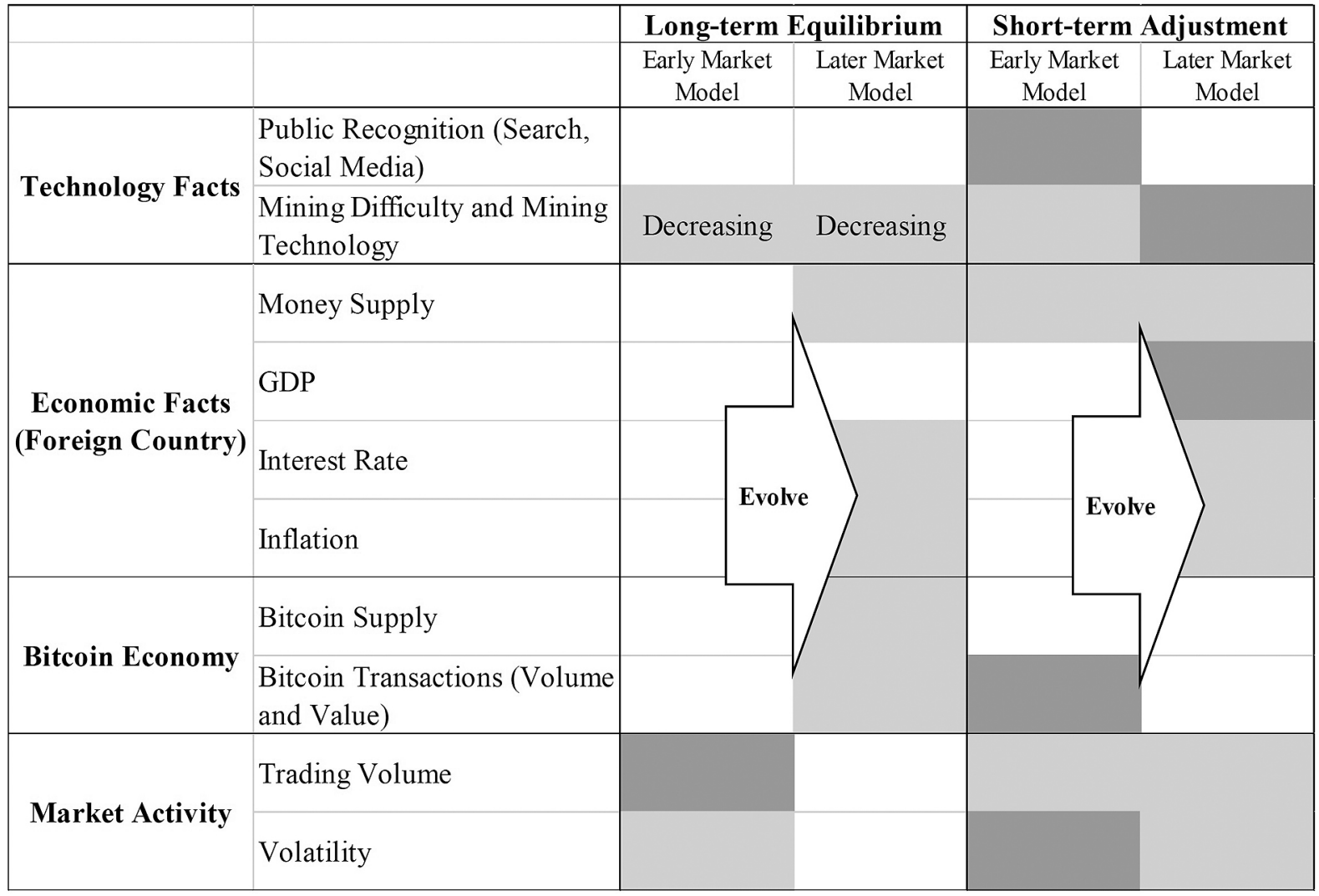

sibility of the increasing in the trading volume and number of nodes.

If the analysis is presented in the historical perspective, the increase in these two parameters is possible to forecast. In the future study, it is possible to show the top three countries graphically by the chosen ratio. These countries are China, Japan and the United States of America.

To make the possibility of bitcoin-based integration more clear it is necessary to take into consideration both technology and economic factors. The figure below summarises the possible factors of mining and bitcoins circulation. From the technology perspective, it is proposed that the bitcoin mining cost has a time-varying effect on the exchange rate based on the inspections.

Meanwhile, the factors that capture public recognition are also included. From an economic perspective, the fundamental economic factors of both the bitcoin economy and the foreign country are included. Trading volume and price volatility are added to capture the impact of market speculation. Not only does the following figure generate a systematic view, but it also includes a more comprehensive set of factors synthesising and extending existing works in this sphere.

In the sphere of bitcoin-based integration, the following hypothesis might be used:

H1A. Mining difficulty has a positive impact on bitcoin's exchange rate.

H1B. The impact of mining difficulty on bitcoin's exchange rate decreases over time,

H2. Public recognition has a positive effect on the bitcoin exchange rate.

H3A. The bitcoin exchange rate reacts to economic indicators of the foreign country, including money supply, inflation rate, interest rate, and GDP.

H3B. The bitcoin exchange rate reacts to a total number of bitcoins in use and transaction volume.

H4. Trading volume and price volatility have significant impacts on the bitcoin exchange rate in the Asian market.

After the principal terms of the hypothesis were mentioned, it is necessary to make a comparison between the Early Market and Later Market.

The empirical analysis confirmed the relevance of both the technical factors and economic factors. Although the market price is anchored on 

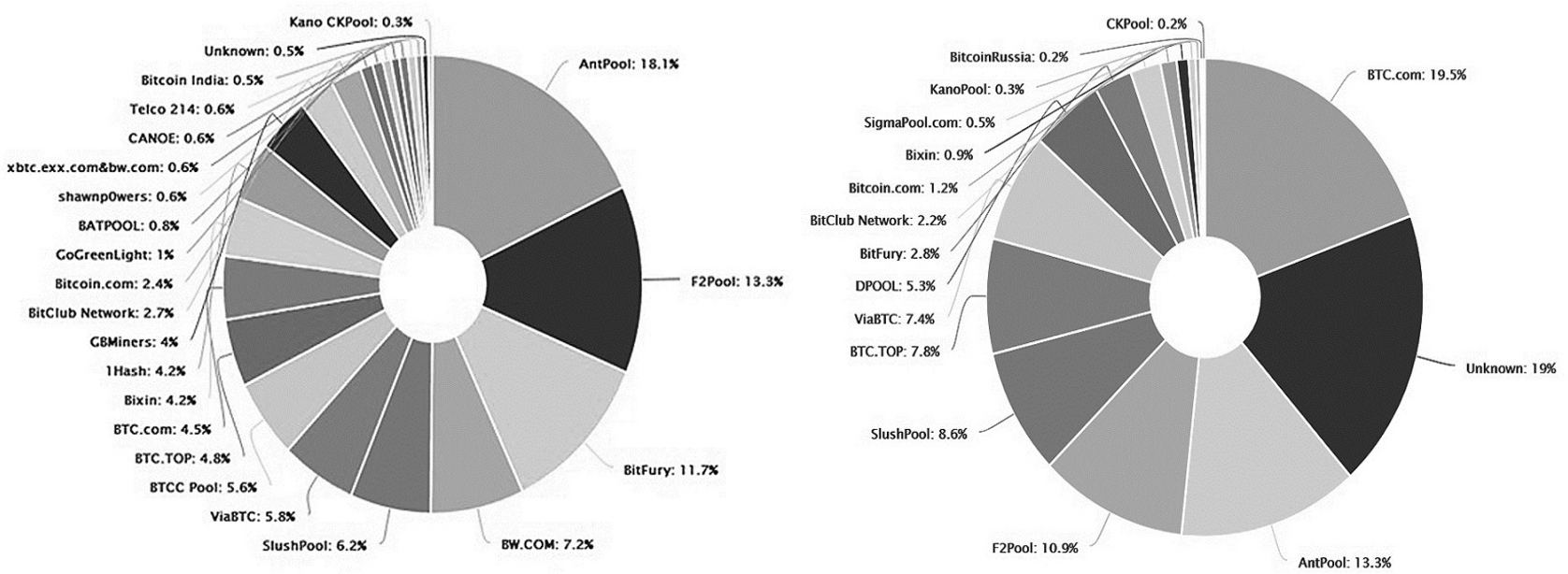

Fig. 6. Hash rate distribution.

Source: https://www.blockchain.com/ru/pools.

mining cost. The long-term impact of mining difficulty diminishes over time as mining technology becomes more efficient. The systematic difference also exists between the early market and the later market. The early market exchange rates are driven predominantly to be a speculative investment and deviate from economic fundamentals (Li \& Wang, 2017, pp. 49-54). Later, the market matured, and the price dynamic followed more closely with changes in the economic factors, while market speculation cast no significant impact in the long term.

The factors determined above are closely connected to the sphere of mining. From the tables, it is seen that China is the leader in mining. Mining is the part of the bitcoin world that is why miningbased Asian integration becomes possible also. Mining integrates the Asian countries, with the head based in China.

Chinese mining pools control more than 60 per cent of the Bitcoin network's aggregate hash rate. Not only does China manufacture most of the world's mining equipment, but also massive mining farms are located there to take advantage of extremely cheap electricity prices. China also accounts for hefty Bitcoin trading volumes. Chinese exchanges used to lead the world in terms of size.

However, Chinese volume has fallen substantially since the PBOC decreed that exchanges could no longer offer 0 per cent trading fees. This ruling flushed a lot of wash trading from the Chinese exchanges. The reasons for China to become the world's leader in Bitcoin mining is listed below:
1. Cheap Electricity. Electricity cost is the most crucial factor for a profitable mining operation. As mining difficulty increases, the least efficient miners are forced to shut down first. Electricity in China is extremely cheap compared to most other countries.

2. Excess Coal. Coal is the cheapest power's source but also the dirtiest. It is well known that China has comparatively lax environmental policies. Major cities like Beijing are notorious for their high levels of smog, produced mostly by burning coal.

3. Leading Bitcoin Mining Pools. Mining pools, as the name implies, are collaborations between individual miners and, frequently, major mining companies. Their hash rate is combined so that the pool has a better chance of finding a block. The block reward is then shared among all contributing members, according to their proportional hash rate.

The result is that many miners outside of China are attracted to Chinese mining pools due to their size. Many miners are lured by the prospect of small, steady earnings as part of a significant pool, as opposed to the high- reward-but-low-odds lottery, which is solo or small-pool mining. China is home to four of the five largest Bitcoin mining pools over the past year.

Before we get into the best mining pools to join, it's important to note that most mining pools are in China. Many only have Chinese websites and support. Mining centralization in China is one of Bitcoin's biggest issues at the moment. There are about 20 major mining pools. Broken down by the percent of hash power controlled by a pool, and the location of that pool's company, we estimate 
that Chinese pools control $\sim 81$ per cent of the network hash rate.

1. BTC.com is a public mining pool that can be joined and mines 15 per cent of all block.

2. Antpool is a mining pool based in China and owned by BitMain. Antpool mines about 11 per cent of all blocks.

3. Slush was the first mining pool and currently mines about 11 per cent of all blocks.

4. F2pool is based in China. It has mined about 10 per cent of all blocks over the past six months.

5. ViaBTC is a somewhat new mining pool that has been around for about one year. It's targeted towards Chinese miners and mines about 9 per cent of all blocks.

6. BTC.top is a private pool and cannot be joined. It mines about 7 per cent of all blocks.

7. DPOOL is a Chinese pool and mines about 4 per cent of all blocks.

8. Bitclub.Network is a large mining pool but appears to be somewhat shady.
9. Bitfury is a private pool that cannot be joined. Bitfury currently mines about 3.5 per cent of all blocks.

10. 58COIN is a Chinese Bitcoin mining pool.

China mines the most bitcoins and therefore ends up "exporting" the most bitcoins. Electricity in China is very cheap and has allowed Chinese Bitcoin miners to gain a very large percentage of Bitcoin's hash power. It's rumoured that some Chinese power companies point their excess energy towards Bitcoin mining facilities so that no energy goes to waste. As indicated above China is home to many of the top Bitcoin mining companies. It's estimated that these mining pools own somewhere around 60 per cent of Bitcoins hash power, meaning they mine about 60 per cent of all new bitcoins. After determining the factors and mining issue of the second scenario of Asian currency integration, it is possible to conclude that the second scenario is preferable and realisable in the short-run.

\section{References}

Antonopoulos Andreas. (2014). Mastering Bitcoin: unlocking digital cryptocurrencies. O’Reilly Media. https://unglueit-files.s3.amazonaws.com/ebf/05db7df4f31840f0a873d6ea14dcc28d.pdf

Brown Ronald C. (2009). Understanding Labor and Employment Law in China. Cambridge University Press. https://doi.org/10.1017/CBO9780511642258

Collier Andrew. (2017). Shadow Banking and the Rise of Capitalism in China. Palgrave Macmillan.

Focus Economics. Economic forecasts from the World's leading economists. http://www.focus-economics.com.

Goldstein Morris, Lardy Nicholas R., eds. (2008). Debating China’s Exchange rate policy. Peterson Institute for International Economics

Green Stephen. (2003). China's Stock market: A guide to its progress, players and prospects. Bloomberg Press.

Hossain Akhand Akhtar. 2015. The Evolution of Central Banking and Monetary Policy in the Asia-Pacific. Edward Elgar Publishing.

HKEX. (2016). HKEX Fact Book.

Kapron Zennon. (2014). Chomping at the Bitcoin. China Penguin Special. e-penguin.

Kroeber Arthur R. (2016). China's Economy: What Everyone Needs to Know? Oxford University Press.

Li X., Wang C.A. (2017). The technology and economic determinants of cryptocurrency exchange rates: The case of Bitcoin. Decision Support Systems, 95, 49-60. https://doi.org/10.1016/j.dss.2016.12.001

Lou Jiwei, Wang Shuilin, eds. 2008. Public Finance in China: Reform and Growth for a Harmonious Society. World Bank Publications. http://documents.worldbank.org/curated/en/255771468216279403/pdf/425630PUB 0Pub1101OFFICIALOUSE 0ONLY 1.pdf

Ming Wang, Jerome Yen, Kin Keung Lai. (2014). China’s Financial Markets: Issues and Opportunities. Routledge.

Minikin Robert, Lau Kelvin. (2012). The Offshore Renminbi. The Rise of the Chinese Currency and Its Global Future. John Wiley \& Sons.

Nakamoto Satoshi. (2008). Bitcoin: A Peer-to-Peer Electronic Cash System. Retrieved from https://bitcoin.org/bitcoin.pdf.

OECD Data, a. Retrieved from https://data.oecd.org/rd/gross-domestic-spending-on-r-d.htm. Accessed 28/02/2019.

OECD Data, b. Retrieved from https://data.oecd.org/natincome/saving-rate.htm. Accessed 28/02/2019.

Sagona-Stophel, Katherine. (n.d.). Bitcoin 101: How to Get Started with the New Trend in Virtual Currencies. White Paper, Thompson Reuters. 
Sanderson Henry, Forsythe Michael. (2013). China's Superbank: Debt, Oil, and Influence - How China Development Bank is Rewriting the Rules of Finance. John Wiley \& Sons Singapore Pte. Ltd.

Shanghai Stock Exchange. (2018). Shanghai Stock Exchange Fact Book. http://english.sse.com.cn/indices/publications/factbook/c/4648486.pdf

Shenggen Fan, Ravi Kanbur, Shang-Jin Wei, Xiaobo Zhang, eds. (2014). The Oxford Companion to the Economics of China. Oxford University Press.

Shenzhen Stock Exchange. (2017). Shenzhen Stock Exchange Fact Book. http://docs.static.szse.cn/www/English/ siteMarketData/publication/factBook/W020181124399499707196.pdf.

Wen-hsin Yeh. (2007). Shanghai Splendor: Economic Sentiments and the Making of Modern China, 1843-1949. Berkeley, University of California Press.

Yu Hua. (2012). China in Ten Words. Anchor Books.

Yulu Chen. (2013). Chinese Currency and the Global Economy: The rise of the Renminbi. McGraw-Hill Education. Zhang Peter G. (2012). The Chinese Yuan: Internationalization and Financial Products in China. John Wiley \& Sons (Asia) Pte. Ltd.

Electronic resources:

Bitcoin charts. https://bitcoincharts.com/charts/volumepie/

Bitcoin nodes https://bitnodes.21.co

Bitcoinity. https://bitcoinity.org/

Bloomberg. https://www.bloomberg.com

Data bitcoinity http://data.bitcoinity.org

\section{Общая характеристика финансовых рынков Китайской Народной Республики}

Мария Аракчеева

Студентка 2-го курса магистратуры,

Международный финансовый факультет,

Финансовый университет, Москва, Россия

Аннотация. Характеризуя состояние экономики и финансовых рынков КНР, автор статьи отмечает: в настоящее время поддержание стабильной национальной валюты для китайского государства становится особенно важным, поскольку значительное влияние на экономическое развитие и состояние международных расчетов в Азиатском регионе оказывает валютно-денежная политика. Открыв в начале 1980-х гг. банковскую систему и четыре государственных специализированных банка для приема депозитов и осуществления банковской деятельности, китайское правительство все последующие годы проводило и проводит взвешенную политику постепенного открытия и либерализации экономики, что позволило Китаю стать второй экономикой в мире. В работе анализируются современные тренды развития финансовых рынков в Китае, даются характеристики и оценки развивающимся рынкам биткоина и криптавалют. Ключевые слова: Китайская Народная Республика; денежно-кредитная политика; экономический рост; криптовалюты; китайские фондовые биржи; юань 